[Report ]

\title{
Anxiety about Starting Three-Shift Work among Female Workers: Findings from the Female Shift Workers' Health Study
}

\author{
Tatsuhiko Kubo ${ }^{1,2}$, Takashi Maruyama ${ }^{1}$, Kiyoyumi Shirane ${ }^{1}$, Hajime Otomoㄹ, \\ Tetsuro MATSUMOTO ${ }^{2}$ and Ichiro OYAMA ${ }^{1,3}$ \\ ${ }^{1}$ Asahi Kasei Health Care Center, Asahi Kasei Nobeoka Office, Nobeoka 882-0873, Japan \\ ${ }^{2}$ Department of Urology, School of Medicine, University of Occupational and Environmental \\ Health, Japan. Yahatanishi-ku, Kitakyushu 807-8555, Japan \\ ${ }^{3}$ Department of Public Health, School of Medicine, University of Occupational and \\ Environmental Health, Japan. Yahatanishi-ku, Kitakyushu 807-8555, Japan
}

A bstract: In 1999, the Japanese Law on Equal Employment Opportunity and Conditions was amended and the previous prohibition of the assignment of female workers to night work was abolished. Subsequently, the number of female shift workers has been increasing in Japan, necessitating greater attention to the health care of this population. The aim of the current study is to evaluate the relationship between anxiety expressed about starting three-shift work and background characteristics among female workers who were being assigned to three-shift work for the first time. The subjects were 38 middle-aged female workers (age range: 44 to 59 years) who were working at a chemical plant. The women completed a self-administered questionnaire before starting three-shift work. Levels of anxiety about starting three-shift work were assessed by the question 'Do you feel anxious about starting three-shift work?' The available responses were: 'Very agree', 'Considerably agree', 'Rather agree', 'Slightly agree' and 'Not agree at all', and 63\% of the subjects gave one of the first two answers, which were defined as indicating anxiety. We also acquired information regarding lifestyle and occupation for each subject, including the following factors: frequency of breakfast consumption, subjective sleep insufficiency, previous experience of similar work before beginning shift work, previous experience of twoshift work, and responsibility for household duties. In the study, we found a marginally statistically significant trend association between frequent breakfast consumption and anxiety about starting three-shift work $\left(P_{\text {trend }}=0.09\right)$. Anxiety was also high among subjects with sleep disorders, especially those suffering from subjective sleep insufficiency $(P=0.08)$. Due to the small study population, these results should be interpreted with caution and confirmed by future studies.

Key words: work schedule tolerance, women, anxiety, shift work, lifestyle, socioeconomic factors.

(Received 3 August 2007, accepted 23 January 2008) 


\section{Introduction}

In Japan, shift work has recently been introduced into various occupational fields and is becoming increasingly common [1]. Chemical industries, for example, operate 24 hours per day, because their production processes often take longer than eight hours and must be performed continuously. Because several industries now operate around the clock, service industries such as restaurants, convenience stores and gas stations have extended their hours to accommodate evening and night-time workers. Ironically, therefore, it is the initial growth in the numbers of shift workers in certain industries that drives the increased need for more shift workers in society as a whole [2] .

Previous studies have reported that shift workers whose circadian rhythms are disrupted are at a high risk of suffering from sleep disturbances, gastrointestinal disturbances, obesity, hypercholesterolemia, hypertension, ischemic heart diseases and some cancers [1,3-7]. Other studies have shown that, compared with their male counterparts, female workers have additional difficulties in maintaining irregular working patterns, both for medical reasons such as menstruation and for social reasons such as having responsibility for housekeeping $[8,9]$. In Japan, the assignment of female workers to night shifts was previously prohibited by the Law on Equal Employment Opportunity and Conditions. However, in 1999 the law was amended and this restriction was abolished. A survey conducted in 2001 revealed that the number of female shift workers was increasing [10]. The health of shift workers therefore became an increasingly important issue in Japan, especially in light of previous reports about the health problems that shift work can cause for women [8, 11-14]. However, most previous surveys have been conducted among subjects who had already been assigned to shift work; studies beginning before the initiation of three-shift work are rare.

Asahi-Kasei Corporation, a manufacturer of innovative products based on chemistry and material sciences, is one of the largest companies in the world. The company introduced three-shift rotating operations by female employees for the first time in 2006 . To monitor the effects of this change in policy on workers' health, the occupational health division of the corporation, Asahi-Kasei Health Care Center conducted a survey of female workers scheduled to start three-shift work: the Female Shift Workers' Health(FSH)study. Based on the findings of the FSH baseline survey, this report discusses the relationship between various lifestyle factors of female workers and their anxiety about starting three-shift work.

\section{Materials and Methods}

\section{Survey}

The subjects of the FSH study were 44 middle-aged female workers (age range: 44 to 59 years; median age: 53) who were employed in the company's chemical plant. All the subjects had been assigned to three-shift rotating operations for the first time. The work to which the subjects were assigned consisted of inspection, checking the quality and quantity of the products. The shift system in place was that of four teams each working three shifts, consisting of three workdays and one rest day per shift. This pattern was repeated in a continuous counterclockwise circulation system. 
The study was designed as a prospective cohort study. The baseline survey was conducted using a self-administered questionnaire in May 2006, prior to the subjects' commencing the three-shift work pattern. Follow-up surveys using self-administered questionnaires were performed three and six months after the initiation of three-shift work. Individual interviews with all subjects were carried out by occupational health nurses after the three-month follow-up survey. The questionnaires were distributed to the subjects through the staff in charge of workplace safety in the plant. The written questionnaire was returned directly to the occupational health staff using the in-company document delivery system. Questionnaires with missing information were returned to the subjects, who were encouraged to provide answers to all the questions. Response rates for each survey were 100\% (44/44 workers) for baseline, $97.5 \%$ (39/40 workers) for the three-month follow-up survey, and $100 \%$ (40/40 workers) for the six-month follow-up survey. As design of the cohort study, lifestyle factors were treated as exposures and subjective adaptation to the shift work or appearances of sleep disturbances were treated as outcomes, respectively. Medical information was collected from the results of general health checkups which were periodically provided by the company under Industrial Health and Safety laws. Four subjects retired or moved to other workplaces between the baseline survey and the three-month follow-up survey.

\section{Anxiety about starting three-shift work}

There were five possible responses to the question assessing anxiety about starting threeshift work, 'Do you feel anxious about starting three-shift work?' : 'Very agree', 'Considerably agree', 'Rather agree', 'Slightly agree' and 'Not agree at all'. In this study, subjects who gave either of the first two responses were defined as being positive for anxiety about starting three-shift work.

\section{Background factors}

From the self-administered questionnaire and the records of general health checkups, we acquired information on the following factors: age, smoking status (non-smoker, current smoker/former smoker), alcohol consumption (non-drinker/former drinker, occasional drinker $(<1$ day per week), habitual drinker $(\geq 1$ day per week), exercise (no, yes ( $>$ once a week)), breakfast consumption ( $\geq 6$ days per week, $4-5$ days per week, $2-3$ days per week, $\leq 1$ day per week), body mass index (BMI), hours of sleep on weekdays, difficulty in initiating sleep (no, yes ( $\geq 3$ days per week)), difficulty maintaining sleep (no, yes ( $\geq 3$ days per week)), subjective sleep insufficiency (no, yes ( $\geq 3$ days per week)), menstruation (yes, no (absence at least for one year)), previous engagement in the same work without shifts (yes, no), previous engagement in two-shift work (yes, no), marital status (single/divorced/ widowed, married), responsibility for child care(yes, no), responsibility for house cleaning (yes, no), responsibility for caring for aged relatives (yes, no). BMI level was categorized according to the BMI classification of the Japan Society for the Study of Obesity [15]. Hours of sleep on weekdays were divided into three categories $(<6$ hours per weekday, 6 hours per weekday, $>6$ hours per weekday). 


\section{Statistical analysis}

We excluded six employees with missing information on at least one of the above-mentioned variables, leaving 38 study subjects. Differences in proportions across categories were assessed using the chi-squared test and Fisher's exact test. Tests of trends across categories of characteristics were calculated by treating the levels of characteristics as a continuous ordinal variable in the regression model. Calculations were performed with SPSS ver.12.0 statistical software.

\section{Approval}

This study was approved by the Ethics Committee for Medical Care and Research, University of Occupational and Environmental Health, Japan.

\section{Result}

Table 1 shows the baseline characteristics of the 38 female workers and prevalence of anxiety about starting shift work according to each baseline characteristics. For baseline characteristics, $63 \%$ of the subjects were positive for anxiety about starting three-shift work. Seventy three percent of the subjects were over 50 years old. Seventy one percent of the subjects partook of breakfast more than six days a week. Sleeping hours on weekdays were surveyed by free reporting; $34 \%$ of the subjects answered that they slept for six hours, and this was the most frequent answer. The rates of prevalence of sleep disorders were $24 \%$ for difficulty in initiating sleep, 29\% for difficulty maintaining sleep, and 68\% for subjective sleep insufficiency. Eighty two percent had previously engaged in the same work without shifts, and $87 \%$ had experience of two-shift work. Regarding house-hold duties, $37 \%$ of the subjects were responsible for child care, $89 \%$ for house cleaning, and $34 \%$ for caring for elderly relatives.

For anxiety about starting three-shift, younger subjects revealed a relatively high prevalence of anxiety $\left(P_{\text {trend }}=0.41\right)$. A higher prevalence of anxiety was observed among subjects who habitually drank alcohol $\left(P_{\text {trend }}=0.17\right)$ and exercised $(P=0.10)$. A marginally statistically significant trend was observed between frequent breakfast consumption and anxiety $\left(P_{\text {trend }}=\right.$ 0.09). Subjects who had high BMI levels also revealed a relatively high prevalence of anxiety $\left(P_{\text {trend }}=0.29\right)$. Subjects who slept for six hours per weekday, which was the most common duration of sleep, revealed a lower prevalence of anxiety $(P=0.23)$. Subjects with sleep disorders, especially who suffered from subjective sleep insufficiency, were more likely to feel anxiety $(P=0.08)$. Subjects with menstruation had a higher prevalence of anxiety $(P=0.18)$. Concerning occupational factors, anxiety was high among subjects who had not previously engaged in similar work $(P=0.23)$, while previous engagement in two-shift work revealed no relation with anxiety $(P=1.00)$. As regards social factors, subjects who were married revealed a high prevalence for anxiety compared to those who were single or divorced $(P=0.30)$. Those who were in charge of house cleaning $(P=0.62)$ and caring for aged relatives $(P=0.73)$ revealed a relatively high prevalence of anxiety compared with the lower prevalence among subjects with child care responsibilities $(P=0.73)$. 
Table 1. Baseline characteristics and prevalence of anxiety about starting shift work of the 38 female workers, the Female Shift Workers' Health(FSH) study, 2006

\begin{tabular}{|c|c|c|c|c|}
\hline Anxiety about starting shift work & $\begin{array}{l}\text { No } \\
\text { Yes }\end{array}$ & $\begin{array}{l}\mathrm{n}(\%) \\
14(37) \\
24(63)\end{array}$ & Prevalence of anxiety $(\%)$ & $P$-value \\
\hline Age & $\begin{aligned} & \leq 49 \\
& 50-54 \\
\geq & 55\end{aligned}$ & $\begin{array}{l}10(26) \\
15(39) \\
13(34)\end{array}$ & $\begin{array}{l}70 \\
67 \\
54\end{array}$ & $0.41^{\mathrm{a}}$ \\
\hline $\begin{array}{l}\text { Lifestyle } \\
\quad \text { Smoking }\end{array}$ & $\begin{array}{l}\text { Non smoker } \\
\text { Current smoker/ former smoker }\end{array}$ & $\begin{array}{r}35(92) \\
3(8)\end{array}$ & $\begin{array}{l}63 \\
67\end{array}$ & $1.00^{\mathrm{b}}$ \\
\hline Alcohol consumption & $\begin{array}{l}\text { Non drinker/former drinker } \\
\text { Occasional drinker } \quad(<1 \text { day /week }) \\
\text { Habitual drinker } \quad(\geq 1 \text { days/week })\end{array}$ & $\begin{array}{r}22(58) \\
6(26) \\
10(26)\end{array}$ & $\begin{array}{l}55 \\
67 \\
80\end{array}$ & $0.17^{\mathrm{a}}$ \\
\hline Exercise & $\begin{array}{l}\text { No } \\
\text { Yes (> once a week) }\end{array}$ & $\begin{array}{l}20(53) \\
18(47)\end{array}$ & $\begin{array}{l}50 \\
78\end{array}$ & $0.10^{\mathrm{b}}$ \\
\hline Breakfast consumption & $\begin{aligned} \geq & 6 \text { days per week } \\
& 4-5 \text { days per week } \\
& 2-3 \text { days per week } \\
\leq & 1 \text { day per week }\end{aligned}$ & $\begin{array}{r}27(71) \\
5(13) \\
5(13) \\
1(3)\end{array}$ & $\begin{array}{c}70 \\
60 \\
40 \\
0\end{array}$ & $0.09^{\mathrm{a}}$ \\
\hline $\begin{array}{l}\text { Physical condition and sleeping habits } \\
\text { Body Mass Index }\end{array}$ & $\begin{array}{ll}\text { Normal range } & (18.5 \leq \sim<25) \\
\text { Obese class I } & (25 \leq \sim<30) \\
\text { Obese class II } & (30 \leq \sim<35)\end{array}$ & $\begin{array}{r}24(63) \\
12(32) \\
2(5)\end{array}$ & $\begin{array}{c}58 \\
67 \\
100\end{array}$ & $0.29^{\mathrm{a}}$ \\
\hline Sleep duration & $\begin{array}{r}<6 \text { hours per weekday } \\
6 \text { hours per weekday } \\
>6 \text { hours per weekday }\end{array}$ & $\begin{array}{l}15(40) \\
13(34) \\
10(26)\end{array}$ & $\begin{array}{l}67 \\
46 \\
80\end{array}$ & $0.23^{\mathrm{c}}$ \\
\hline Difficulty in initiating sleep & $\begin{array}{l}\text { No } \\
\text { Yes ( } \geq 3 \text { days per week) }\end{array}$ & $\begin{array}{r}29(76) \\
9(24)\end{array}$ & $\begin{array}{l}59 \\
78\end{array}$ & $0.44^{\mathrm{b}}$ \\
\hline Difficulty maintaining sleep & $\begin{array}{l}\text { No } \\
\text { Yes ( } \geq 3 \text { days per week) }\end{array}$ & $\begin{array}{l}27(71) \\
11(29)\end{array}$ & $\begin{array}{l}59 \\
73\end{array}$ & $0.49^{b}$ \\
\hline Subjective sleep insufficiency & $\begin{array}{l}\text { No } \\
\text { Yes ( } \geq 3 \text { days per week) }\end{array}$ & $\begin{array}{l}12(32) \\
26(68)\end{array}$ & $\begin{array}{l}42 \\
73\end{array}$ & $0.08^{\mathrm{b}}$ \\
\hline Menstruation & $\begin{array}{l}\text { Yes } \\
\text { No (absence for } \geq 1 \text { year) }\end{array}$ & $\begin{array}{l}18(47) \\
20(53)\end{array}$ & $\begin{array}{l}75 \\
50\end{array}$ & $0.18^{\mathrm{b}}$ \\
\hline $\begin{array}{l}\text { Occupational factors } \\
\text { Previous engagement in the same work } \\
\text { without shifts }\end{array}$ & $\begin{array}{l}\text { No } \\
\text { Yes }\end{array}$ & $\begin{array}{r}7(18) \\
31(82)\end{array}$ & $\begin{array}{l}86 \\
58\end{array}$ & $0.23^{b}$ \\
\hline Previous engagement in two-shift work & $\begin{array}{l}\text { No } \\
\text { Yes }\end{array}$ & $\begin{array}{r}5(13) \\
33(87)\end{array}$ & $\begin{array}{l}60 \\
64\end{array}$ & $1.00^{\mathrm{b}}$ \\
\hline $\begin{array}{l}\text { Social factors } \\
\text { Marriage status }\end{array}$ & $\begin{array}{l}\text { Single/ divorced/ widowed } \\
\text { Married }\end{array}$ & $\begin{array}{l}12(32) \\
26(68)\end{array}$ & $\begin{array}{l}50 \\
69\end{array}$ & $0.30^{b}$ \\
\hline Responsible for child care & $\begin{array}{l}\text { Yes } \\
\text { No }\end{array}$ & $\begin{array}{l}14(37) \\
24(63)\end{array}$ & $\begin{array}{l}57 \\
67\end{array}$ & $0.73^{b}$ \\
\hline Responsible for house cleaning & $\begin{array}{l}\text { Yes } \\
\text { No }\end{array}$ & $\begin{array}{r}34(89) \\
4(11)\end{array}$ & $\begin{array}{l}65 \\
50\end{array}$ & $0.62^{b}$ \\
\hline Caring for elderly relatives & $\begin{array}{l}\text { Yes } \\
\text { No }\end{array}$ & $\begin{array}{l}13(34) \\
25(66)\end{array}$ & $\begin{array}{l}69 \\
60\end{array}$ & $0.73^{b}$ \\
\hline
\end{tabular}

a: $P$ indicates trend association, $b$ : $P$-value derived from Fisher's exact test, $c$ : $P$-value derived from chi-squared test 


\section{Discussion}

In the baseline survey of the FSH study, we found a marginally statistically significant trend association between frequent breakfast consumption and anxiety about starting three-shift work $\left(P_{\text {trend }}=0.09\right)$. Anxiety was also high among subjects with sleep disorders, especially those suffering from subjective sleep insufficiency $(P=0.08)$. In this section, some tentative hypotheses based on the findings of this study will be put forward.

Regarding age factors, the subjects belonging to the youngest category ( $44-49$ years old) revealed the highest prevalence of anxiety, and the prevalence declined with age. Similarly, Oginska et al reported that female shift workers' subjective health complaints were most frequent at 40-50 years old, while the prevalence of these complaints declined with age [13]. Oginska suggested that after passing the age of 50, women tend to become more free from house-hold responsibilities, included taking care of young children, and that older women might perceive work as having a beneficial effect on their physical and psychological wellbeing [13]. In the FSH study, the younger subjects were more likely to be responsible for child care (data not shown); however, no direct association was observed between anxiety about starting three-shift work and the social factors including child care, house cleaning and caring for aged relatives. Why the subjective complaints regarding shift work are high among women of the age 40-49 compared with older women is still controversial.

Concerning lifestyle factors, subjects who frequently consumed breakfast, exercised and habitually drank alcohol revealed a relatively high prevalence of anxiety. As regards alcohol consumption, information about the frequency of drinking and the amount of drinking per day was recorded at general health checkups. According to that, only one subject of the drinkers drank every day, and the amount she drank in a day was less than 1 unit (one unit $=$ alcohol $27 \mathrm{~g}$ ) a day. The daily amount of drinking of the other subjects who drank alcohol was also two units a day at most. Their drinking habits could be regarded as relatively favorable from a health point of view [16]. These results could be interpreted as indicating that subjects who had better lifestyles tended to feel more anxious about starting shift work, perhaps due to concern about the disruptive effect of shift work on their lifestyles.

A high prevalence of anxiety was revealed among subjects with high BMI levels or with sleep disorders, especially subjective sleep insufficiency. It has been widely reported that shift work is a risk factor for obesity and sleep disorders $[1,3,17]$. Furthermore, a disturbed lifestyle, including disruption of sleep and dietary patterns due to shift work, are the main complaints of shift workers [13]. The awareness among subjects of these problems was not investigated; however, it seems reasonable that subjects who are conscious of existing problems related to their body weight or sleep quality tend to feel anxious at the prospect of starting shift work. Subjects with menstruation revealed a relatively high prevalence of anxiety. Perimenopausal syndrome can result from a wide variety of causes, including psychosocial factors $[18,19]$. The subjects of this study were middle-aged women, and that might therefore have had some effects on these results.

Six hours sleep per weekday was the most commonly reported sleep duration among subjects of the current study. The average sleep hours of Japanese women of the 50-59 yearold age group have previously been reported to average 6 hours and 51 minutes [20]. This discrepancy can be explained by the finding that people who have jobs usually have shorter 
sleeping hours compared with those who do not [20]. The hours of sleep reported by the subjects of the current study might therefore represent the average sleeping hours for Japanese working women. Subjects in this study who reported more or fewer hours of sleep revealed a higher prevalence of anxiety compared to the average. It was previously reported that both longer and shorter durations of sleep are associated with decreased subjective sleep sufficiency and increased symptoms of depression [21]. Hours of sleep could therefore be one predictive factor for anxiety about starting three-shift work.

The subjects who had previously engaged in similar work had a lower prevalence of anxiety. This indicates that, by allowing workers an opportunity to experience the work they will be doing before starting three-shift work, anxiety felt by female workers about starting three-shift work could be reduced. On the other hand, there was no difference in the prevalence of anxiety among subjects with or without previous experience of two-shift work. In the Asahi-Kasei plant, two-shift work involves day and evening shifts but no night shift. Working on night shifts is the crucial factor in the negative health effects observed as a result of shift work [22]. Giving workers experience of two-shift work in preparation for three-shift work might not, therefore, have the effect of reducing anxiety about starting three-shift work.

\section{Study limitations}

The present study had several limitations. First, the validity of our questionnaire assessing the anxiety to start three-shift work has not been investigated. Consequently, analyses using other questionnaires might provide different results. Second, the number of subjects was relatively small to positively ascertain results. The results should therefore be interpreted with caution and confirmed in other settings. Last, background characteristics and anxiety were assessed neither independently nor objectively. Thus, workers with anxiety might have overstated health conditions such as subjective insufficiency of sleep, leading to a stronger association with anxiety about starting three-shift work.

\section{Conclusions}

The FSH study revealed a marginally statistically significant association between frequent breakfast consumption, subjective sleep insufficiency, and anxiety about starting three-shift work among middle-aged female workers. The study provided the hypotheses that women aged 40-49 years old who have a good lifestyle, including regularly eating breakfast, taking exercise and consuming moderate amounts of alcohol, as well as those who suffer from obesity or sleep disorder and those without previous experience of similar work, are at a high risk of experiencing anxiety about starting three-shift work. To allow workers the experience of doing the same work without the shift pattern and to treat sleep disorders before employees begin three-shift work might help female workers to reduce anxiety related to starting to work this shift pattern.

\section{Acknowledgements}

The authors express their sincere appreciation to all the Asahi-Kasei staff involved in this study. The authors also thank Hiroyuki Kanaoka for supervisory support; Hirofumi 
Enokizono, Masahiro Tomokiyo, Keiichi Kinoshita, Masahiro Kawano for their insights into occupational health care and occupational medicine; Shoko Yonemitsu, Yoriko Uesugi, Kayoko Fujita, Tomiko Nakashima, Makiko Nariai for their dedicated support work.

Conflict of interest: none declared.

\section{References}

1. Motohashi Y \& Higuchi S (1999): Shift work and health. Occupational Health Review 12 (3): $125-144$ (in Japanese)

2. Rosa RR \& Colligan MJ (1997): Plain language about shiftwork. U.S. Department of Health and Human Services. http://www.cdc.gov/niosh/pdfs/97-145.pdf

3. Akerstedt T (2003): Shift work and disturbed sleep/wakefulness. Occup Med 53 (2): $89-$ 94

4. Fujino $Y$, Iso H, Tamakoshi A, Inaba Y, Koizumi A, Kubo T \& Yoshimura T; Japanese Collaborative Cohort Study Group (2006): A prospective cohort study of shift work and risk of ischemic heart disease in Japanese male workers. Am J Epidemiol 164 (2): 128 135

5. Megdal SP, Kroenke CH, Laden F, Pukkala E \& Schernhammer ES (2005): Night work and breast cancer risk: A systematic review and meta-analysis. Eur J Cancer 41: $2023-$ 2032

6. Schernhammer ES, Laden F, Speizer FE, Willett WC, Hunter DJ, Kawachi I, Fuchs CS \& Colditz GA (2003): Night-shift work and risk of colorectal cancer in the nurses' health study. J Natl Cancer Inst 95: 825 - 828

7. Kubo T, Ozasa K, Mikami K et al (2006): Prospective cohort study of the risk of prostate cancer among rotating-shift workers: findings from the Japan collaborative cohort study. Am J Epidemiol 164: 549-555

8. Novak RD, Smolensky MH, Fairchild EJ \& Reves RR (1990): Shiftwork and industrial injuries at a chemical plant in southeast Texas. Chronobiol Int 7(2): 155-164

9. Labyak S, Lava S, Turek F \& Zee P (2002): Effects of shiftwork on sleep and menstrual function in nurses. Health Care Women Int 23(6-7): 703-714

10. Ministry of Health, Labour \& Welfare (2002): Female employment management foundamental report 2001 http://www.mhlw.go.jp/houdou/2002/05/h0524-5.html (in Japanese)

11. Sveinsdottir H (2006): Self-assessed quality of sleep, occupational health, working environment, illness experience and job satisfaction of female nurses working different combination of shifts. Scand J Caring Sci 20: 229-237

12. Sudo N \& Ohtsuka R (1999): Sleep patterns and sleep disorders among female shift workers in a computer factory of Japan. J Hum Ergol 28(1-2): 39-47

13. Oginska H, Pokorski J \& Oginski A (1993): Gender, ageing, and shiftwork intolerance. Ergonomics 36(1-3): $161-168$

14. Sekine M, Chandola T, Martikainen P, Marmot M \& Kagamimori S (2006): Work and family characteristics as determinants of socioeconomic and sex inequalities in sleep: The Japanese Civil Servants Study. Sleep 29: 206-216

15. Kanazawa M, Yoshiike N, Osaka T, Numba Y, Zimmet P \& Inoue S (2005): Criteria and classification of obesity in Japan and Asia-Oceania. World Rev Nutr Diet 94: 1- 12 
16. Tsugane S, Fahey MT, Sasaki S \& Baba S (1999): Alcohol consumption and all-cause and cancer mortality among middle-aged Japanese men: seven-year follow-up of the JPHC study Cohort I. Japan Public Health Center. Am J Epidemiol 150: 1201-1207

17. Di Lorenzo L, De Pergola G, Zocchetti C, L’Abbate N, Basso A, Pannacciulli N, Cignarelli M, Giorgino R \& Soleo L (2003): Effect of shift work on body mass index: results of a study performed in 319 glucose-tolerant men working in a Southern Italian industry. Int J Obes Relat Metab Disord 27: 1353- 1358

18. Woods NF \& Mitchell ES (2005): Symptoms during the perimenopause: prevalence, severity, trajectory, and significance in women's lives. Am J Med 118 Suppl 12B: 14-24

19. Rasgon N, Shelton S \& Halbreich U (2005): Perimenopausal mental disorders: epidemiology and phenomenology. CNS Spectr 10: $471-478$

20. Japan Broadcasting Corporation (2006): National Time Use Survey 2005 Report. http:// www.nhk.or.jp/bunken/research/life/life_20060210.pdf(in Japanese)

21. Kaneita Y, Ohida T, Uchiyama M, Takemura S, Kawahara K, Yokoyama E, Miyake T, Harano S, Suzuki K \& Fujita T (2006): The relationship between depression and sleep disturbances: a Japanese nationwide general population survey. J Clin Psychiatry 67: $196-203$

22. Sakai K (2005): Heatlh care for rotating shift workers and night shift workers. 7 th $e d$. Guidance for Occupational Physicians. Tokyo Medical Association, Tokyo pp179-186 (in Japanese) 
三交代勤務開始前に女性労働者の間に生じる勤務への不安：FSH スタディー

久保 達彦 1,2 , 丸山 崇 ${ }^{1}$, 白根 聖弓 ${ }^{1}$, 大友 - $^{1}$, 松本 哲朗 ${ }^{2}$, 小山 一郎 1 ,

${ }^{1}$ 旭化成延岡支社 環境安全部 健康管理センター

2 産業医科大学 医学部 泌尿器科学講座

3 産業医科大学 医学部 公衆衛生学講座

要 旨: 平成11 年に労働基準法の女性深夜労働禁止規定が撤廃され, 本邦では女性深夜 業従事者数は増加傾向にある. 本報告では初めて三交代勤務に従事する女性 44 名 $44-59$ 歳)を対象に, 就業前に生じる“三交代勤務開始への不安”の分布状況 を生活習慣や社会的要因との関連に扔いて記述疫学的に報告する。調查は三交 代開始前に自記式調查票を用いて行われた。不安の評価は「三交代勤務を始める ことに不安があるか？」という質問に対し[非常に/かなり]と解答した者を不安 症例, [少し/わずかに/ぜんぜんない]と解答した者を対照とすることで行われ た。その結果, 朝食の摂取頻度が高いもの $\left(P_{\text {trend }}=0.09\right)$ と睡眠障害の中でも特に 熟眠障害を有する者 $(P=0.08)$ では就業不安の発生頻度が高い傾向が認められた。

キーワード：樑夜業, 交代制勤務, 女性, 不安, 生活習慣, 社会経済的要因.

J UOEH（産業医科大学雑誌）30(1):1-10(2008) 